\title{
Character Education Values Used in the Avengers: Endgame Movie
}

\section{Anggun Purnomo Arbi}

\author{
STKIP PGRI Sidoarjo, Email: anggunpurnomo58@gmail.com
}

\begin{abstract}
This research was aimed to describe the character education values used in the Avengers: End Game Movie. Movie is described as the series of moving pictures combined with sound effects. Character education values. This study applied library research as it described the results of study. The data of this study were the phenomena and facts classified into the character education values. The source of data were the facts or phenomena shown in the movie scenes and the movie transcription of Avengers: Endgame. This study used two instruments called: the researcher himself and the documentation. The object of this study was a movie entitled "Avengers: Endgame". In collecting the data of this research, the researcher used documentary technique including watching the movie, reading the movie's screenplay and taking a note. The researcher used the theory of content analysis (Ary, 2010) to analyze the data. Based on the results of the study, the researcher found eight types of character education values covering: responsibility, honesty, hardworking, tolerance, curiosity, patriotism, creativity, and communicativeness.
\end{abstract}

Keywords: Character education values, Movie, Avengers: Endgame

\section{INTRODUCTION}

Viewed from the 2013 curriculum, character education program becomes the main feature of curriculum 13 (K13) (Faiziyah \& Fachrurrazy, 2013). This program has been socialized since 2010 by the government, so schools must implement this program. In Indonesia, teachers has responsibility to teach both knowledge and character educations to the learners. To strengthen those reasons, the values of character education should be included or integrated in a teaching process. To include the character education values is a steps of building character education. There are some ways of building values of education character including through movie (Esianita \& Widyawati, 2020, p. 2).

Movie, a kind of media, has essential influences in giving information and delivering messages to people who watch it (Mukarromah, 2019, p. 38). As an audio visual media, movie can be used in the process of building emotion, attitude, and also solving the problems (Mukarromah, 2019, p. 37). Considering the these reasons, movie can be chosen as a media that can build the character education values, so the researcher intended to analyze the character educational values trough movie. In analyzing character education values trough movie, there are some released movies that are very interesting. One of the interesting movie is Avengers: Endgame. It means that this study intended to analyze character education in the movie entitled "Avengers Endgame" based on the reasons considered below.

The first reason, using a movie as a media of analyzing character education value is very important because it has important roles in transferring educational aspects. Nowadays, many educational elements like educational values may be presented in the literary works such 
as movie (Jannah, 2018). It means that movies do not only entertain the viewers but also reflect character educational values. The educational values, in movie, can be reflected from character, characters' behavior, movie's setting, movie's plot, conflicts, audio, visual, and so fourth.

The second reason, based on internet movie database, the movie entitled "Avengers: Endgame was rated 8.4/10 points, it means that this movie had great scores (IMDb, 2019). This rating scre was voted by more than 865,101 Avengers: Endgame viewers or IMDb registered users. The score showed that mostly viewers rated this movie positively. Because the rating of this movie was great, the audience or someone who will watch this movie is motivated to watch this movie. Those reasons can be the considerations of choosing Avengers: Endgame as the object of this study.

The third reason, it is essential to analyze a movie because of its persuasive point. One persuasive plot of movie can be called plot. Because movie has interesting plot, it becomes effective media to persuade people mind (Esianita \& Widyawati, 2020, p. 1). Movie can persuade people to be better in real life as it reflects hidden values. Those values are reflected from movie's audio visual, settings, story line, characters and so fourth because movie, sometimes, related to the real life. Based on those reasons, movie can influence and motivate the viewers because it relates to people's life.

The fourth reason, character education values help students character in developing essential human qualities covering: diligence, compassion, justice, respect, courage and so fourth (Pala, 2011, p. 26). By learning the character education, students can learn how live positively when implementing values of character education. For example, in the classroom, the teacher tecahes the students about education value "hardworking", and the students implement this character education by studying hard in order to reach better achievement in school.

The last reason, the character education values are very important aspect of education as it helps the people in reaching their objectives of life (Mardewi, Wanto, \& Indriyani, 2020, p. 50). It means that character education values help ones to improve their character positively. The process of character education is the process to form psychology, physical structure and also personality in a balanced personality (Khoirina in Mardewi, Wanto, \& Indriyani, 2020). Based on the reasons stated above, the researcher intended to conduct a study entitled "Character Education Values used in the Avengers: Endgame Movie". Considering the background of the study, the researcher formulated a statement of the problem as "What are the types of character education values used in the Avengers: Endgame movie?" 


\section{LITERATURE REVIEW}

This part contained some theories and concepts that supported this study. Those theories and concepts included the definition of character education values, the classification of the types of character education values, the definition of movie, the introduction to Avengers: Endgame, and also the synopsis of Avengers: Endgame movie. Those theories and concepts were described as they support the researcher to collect and analyze the data of this study.

\section{Character Education Value}

As the schools started the application of curriculum 2013, character education was implemented in Indonesia (Wardani, Tasnim, \& Eko B, 2019, p. 232). It means that the character education values should be developed when the teacher taught cognitive, psychometric, and also affective domain. Moreover, based on curriculum 2013 (K13), the focus of education was to have good cognitive domain and good character education values. Thus, teachers have responsibility to apply the character education in teaching and learning process.

Based on the characteristic of character education values, it can be classified into several types. Character education values can be divided into 18 types that should be integrated in the teaching process by the teacher. The types of character education values were religiousity, democracy, patriotism, honesty, creativity, responsibility, independent, good reader, discipline, national spirit, communicativeness, appreciation, peace lover, environmental care, curiousity, sociality, tolerance, and hardworking (Kemendiknas, 2010).

\section{Movie}

Literature can be formed in some types. One type of literature or literary work is called a movie. Movie can be described as the recorded stories as a set of moving pictures with sound effects, it is shown in a cinema, TV, and the others audio visual gadgets (Hornby in Jannah, 2018, p. 14). Some movies are based on the real life, but some of them are fictive. Whether it is fictive or not, movie can bring the messages that cannot be learned from classroom. The messages are involved by the authors ion order to make the story be more affective.

\section{Avengers: Endgame}

Avengers: Endgame or Avengers 4 is the popular 2019 Super hero movies produced by Marvel Studios in America. This movie was adapted from the Marvel super heroes comics that has similar title "Avengers". This movie whose genres are actions, drama, and adventure presents incredible super heroes' actions supported by amazing visual effects. This movie used English as the main language of this movie. Kevin Feige was the producer of this Movie. It was a sequel to The Avengers (2012), Avengers: Age of Ultron (2015), Captain America Civil 
War, Avengers: Infinity War (2018), Ant Man and the Wasp (2018), and Captain Marvel (2019).

\section{Synopsis of Avengers: Endgame}

In Infinity War movie, Thanos defeat Avengers and he collected all infinity stones that has power to kill half of population. Thanos finally uses the power of infinity stone implanted in infinity gauntlet, so millions creatures in the univerese passed away. After Thanos, the main avengers' enemy, wiped out the half of populations, the universe is not balance. The rest of Avengers including Captain America, Iron Man, Hulk, Thor, War Machine, Black Widow, Hawkeye, Nebula, Rocket Racoon and Ant Man assembled again in order to create the time travel machine. They tried to go to the past and collected the infinity stones in order to balance the universe.

\section{METHOD}

Viewed from its setting, this study can be classified as the library research as the source of data was from documents called Avengers: Endgame movie. Library research is research on written or recorded materials such as books, documents, magazines, scientific journals, tabloid, newspapers and (Mahmud, 2016, p. 5). The data of this study were the phenomena and facts classified into the character education values. The source of data were the facts or phenomena shown in the movie scenes and the movie transcription of Avengers: Endgame. This study used two instruments called: the researcher himself and the documentation covering. The object of this study was a movie entitled "Avengers: Endgame".

In collecting the data of this research, the researcher used documentary technique including watching the movie, reading the movie's screenplay and taking a note. To analyze the data, the researcher used the theory or concepts of content analysis by (Ary, 2010, p. 458). Those steps of data analysis were represented as follow: First, the researcher specified the phenomena that was investigated (the phenomena in this study mean the character education values). Second. the researcher selected the media (the media of this study refers to movie entitled "Avengers: Endgame "). Third, the researcher formulated exhaustive and also mutually exclusive coding classification (the instruments used in this study were based on the needs of analyzing types of character education values covering 18 types). Fourth, the resercher used two instruments including the researcher and the documentation in order to analyze the data. Fifth, the researcher made a summary or conclusion of the results of the study. 


\section{FINDINGS AND DISSCUSSION}

In this part, the answers of the stated problem were described by the researcher. The problem of this study was about the types of character education value reflected on the Avengers: Endgame movie. As this study was a descriptive qualitative study, the findings or results of this study were described in the form of description and narration. The findings and discussion related to the theories of types of character education values cited in (Kemendiknas, 2010).

\section{Types of Character Education Value}

Character education referred to the national program that makes schools foster ethical, responsible, and caring the young people through teaching good characters by focusing on the universal values (Pala, 2011, p. 24). Types of character education values can be described as the classification character education values based on their characteristics. Character education values can be divided into 18 types that should be integrated in the teaching process by the teacher. The types of character education values were religiousity, democracy, patriotism, honesty, creativity, responsibility, independent, good reader, discipline, national spirit, communicativeness, appreciation, peace lover, environmental care, curiousity, sociality, tolerance, and hardworking (Kemendiknas, 2010). In conducting this study, the researcher emphasized on analyzing the types of character education values on the movie entitled “Avengers: Endgame". Those types of character education values were represented below:

In this study, the researcher found eight types of character education values. They were responsibility, honesty, hardworking, tolerance, curiosity, patriotism, creativity, and communicativeness. It means that the researcher did not find 10 types of character education values namely religiousity, democracy, independent, good reader, discipline, appreciation, peace lover, environmental care, sociality and national spirit. In addition, 8 types of character education values found in the Avengers: Endgame movie were described below:

\section{\#Responsibility}

The first type of character education values found in the Avenger: Endgame was responsibility. Responsibility, being responsible, was an action of being someone whose duty is dealing with something, behaving correctly, caring for someone, and being trusted. The one who is responsible has an obligation to do something. Based on data analysis, the first type of character education was 'responsibility reflected from the scene when Hawkeye taught his daughter (Lila) to become skilled archer. 


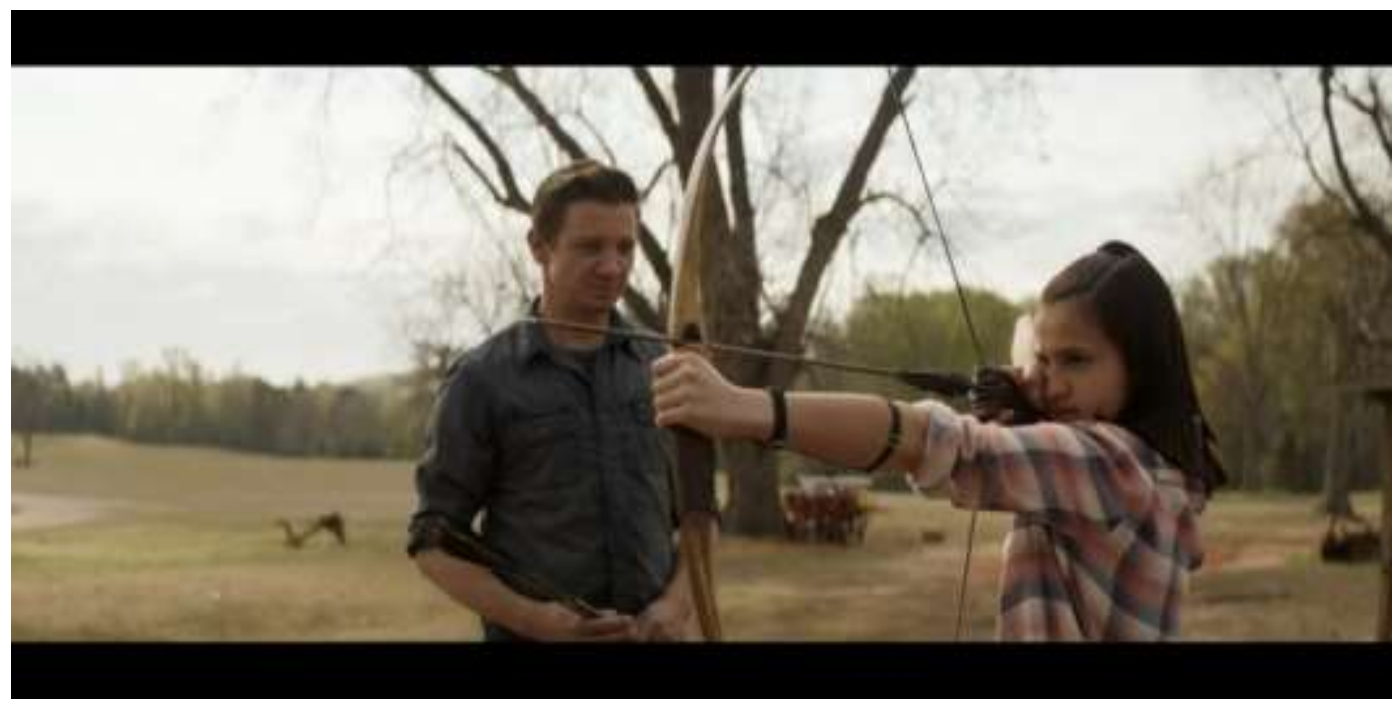

Figure 1. Hawkeye Teaches Lila to Use Archer's Bow

Source: Avengers: Endgame

Hawkeye guided Lila to shoot the target. Lila enthusiastically did what Hawkeye guided. From this scene, we knew that Hawkeye did his responsibility as a father. He was caring for Lila's future, so he strove to make her daughter a professional archer. This character education is should be implemented in school because it will make the students be better in social life. They will have the duty of taking care their environment.

\section{\#Hard working}

Hard working can be described as a great point of character education values. It is the behavior of showing hard efforts to reach or achieve goals. People who have hardworking character never stop their actions until they achieve their goals or dreams. In the Avengers: Endgame, the character education value 'hard working' can be seen in the scene when the whole avengers strove to defeat Thanos.

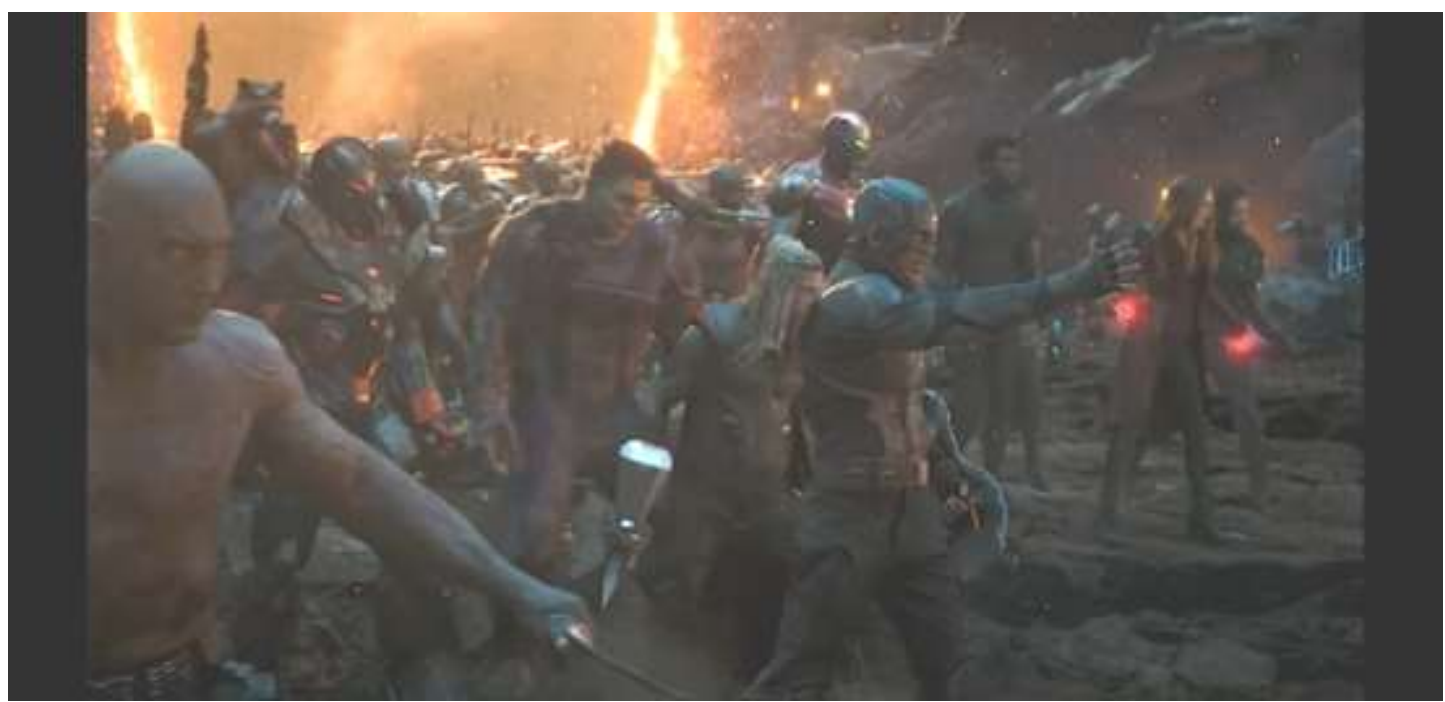

Figure 2. Avengers' Striving

Source: Avengers: Endgame 
Hardworking can be reflected from avengers' struggle. The Avengers worked hard to collect all the infinity stones in the past by using time travel, and they went back to the present time in order to use the powers of infinity stones for balancing the universe. Moreover, the Avengers did worked hard to defeat their powerful enemy called Thanos. In education, hardworking is a great character that should be implemented in classroom. Students should work hard in order to achieve the better achievements.

\section{\#Honesty}

One commendable character education found in the Avengers: Endgame was 'honesty'. Honesty, to be honest, is an action of telling the truth or not being liar, so to be honest can be called as truthfulness. Character education 'honesty' is also a behavior of being sincere, loyal, and also fair. This type of character education value can be reflected from the scene when Nebula describes that Thanos never lies.

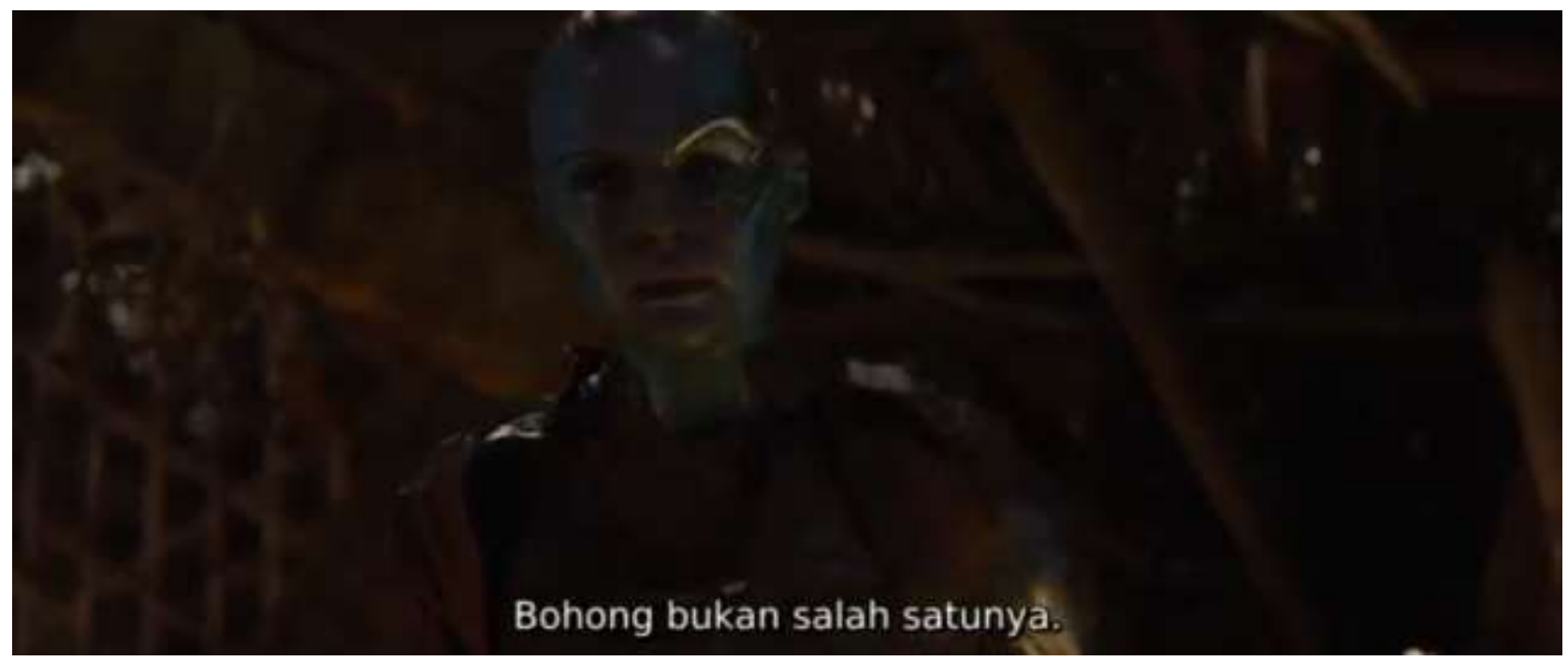

Figure 3. Nebula describes Thanos's Truth

Source: Avengers: Endgame

However Thanos is the main villain of Avengers, he was described as the honest character in the Avengers: Endgame movie. Thanos always tells the truth although he is in the worst situation. The Thanos daughter, Nebula, tells that Thanos did a lot of crimes, but lying was not his crime. Thanos always says truth when he expresses his love to his daughter namely Nebula and Gamora.

\section{\#Tolerance}

Toleration or being tolerant is the action that permits or allows the action, object, idea, or person disliked or rejected by the others. Tolerance is an action or behavior that understands and respects the differences between humans. The character education 'tolerance' was reflected 
in the Avengers: Endgame movie especially in the scene when Captain America, Steve Rogers invited depressed people who are sad because of the loss of their loved ones in the murder committed by Thanos to confide in their problems.

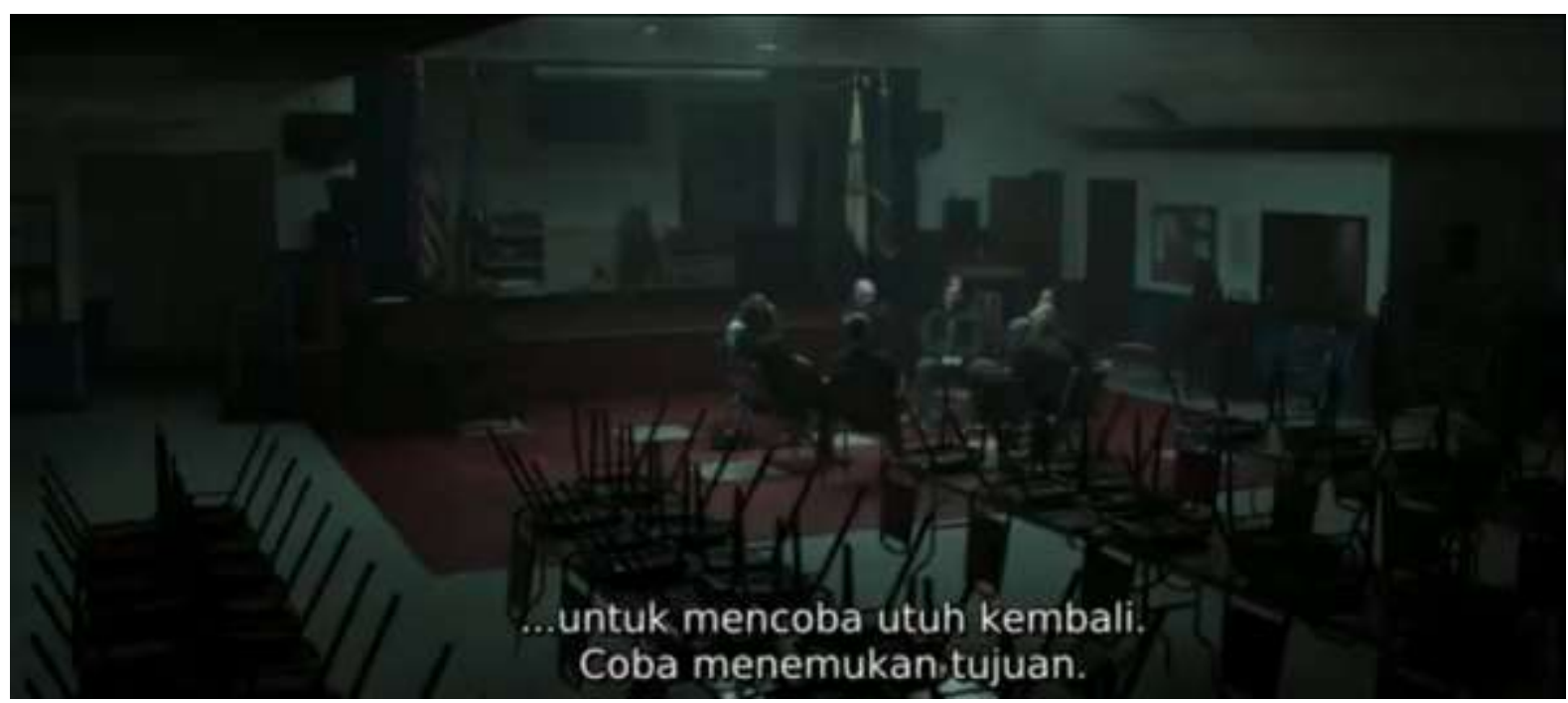

Figure 4. Captain Amreica's Toleration

Source: Avengers: Endgame

\section{\#Patriotism}

The character education value 'patriotism or becoming patriotic can be described as attitude or behavior that involves underlying, bravery and willing to sacrifice himself/herself for the nation. Patriotism can be called as the spirit of loving and protecting the hometown (Rahayu in Esianita \& Widyawati, 2020). The patriotism value, in this study, was reflected from the scene when Captain America, Iron Man, and Thor sacrifice themselves for protecting Earth from Thanos.

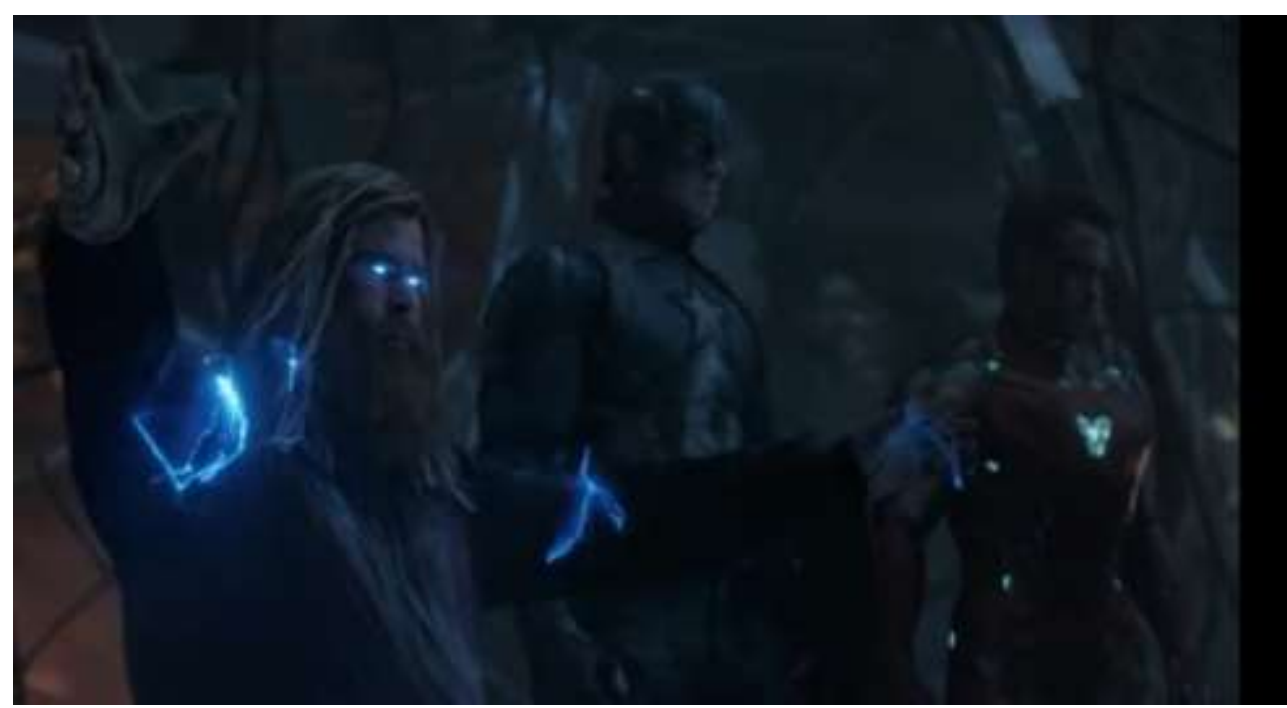

Figure 5. Avengers Protect Earth

Source: Avengers: Endgame

The main Avengers members (Captain America, Iron Man, and Thor) had patriotism spirit as they exert all strengths and efforts in order to defeat Thanos. Although they knew how 
strong Thanos were, Avengers sacrifice their life for preventing the destruction of the Earth. In Addition, Black Widow, Natasha Romanof, was willing to sacrifice her soul so that Avengers got the soul stones to stop Thanos. In Education, patriotism should be implemented as it can motivate the students in order to build great character in school.

\section{\#Curiousity}

Curiousity, to be curious, is a type of character education value reflected from Avengers: Endgame movie. It is the activity of investigating the secrets of nature deeply. In the other words, the value of curuousity is the action or striving done by people to find out deeply what we see, hear, and learn (Esianita \& Widyawati, 2020). This action can motivate people to discover new things. The value of curiosity was reflected from the scene when the rest of Avengers tried hard to think the way of creating time travel machine. In the beginning, the avengers was curios about the location of Thanos.

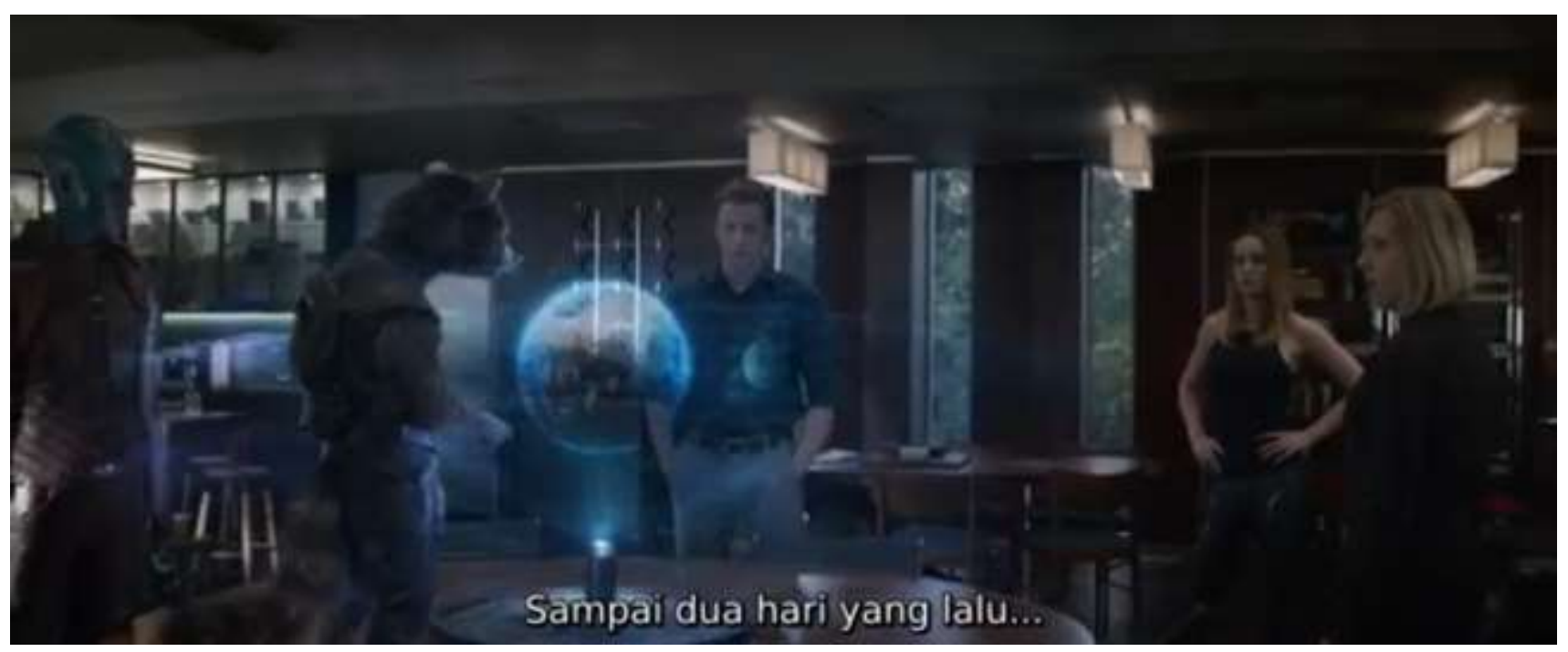

Figure 6. Finding Thanos's Location

Source: Avengers: Endgame

\section{\#Creativity}

The next type of character education value was 'cretivity. The value of creativity was described as an ability to create, to think, and to act by using experiences, knowledge, understanding, insight, and also common sense (Esianita \& Widyawati, 2020). It means that creativity is an action of implementing the experimental self knowledge. This values of education was reflected from the scene of creating the time travel machine. 


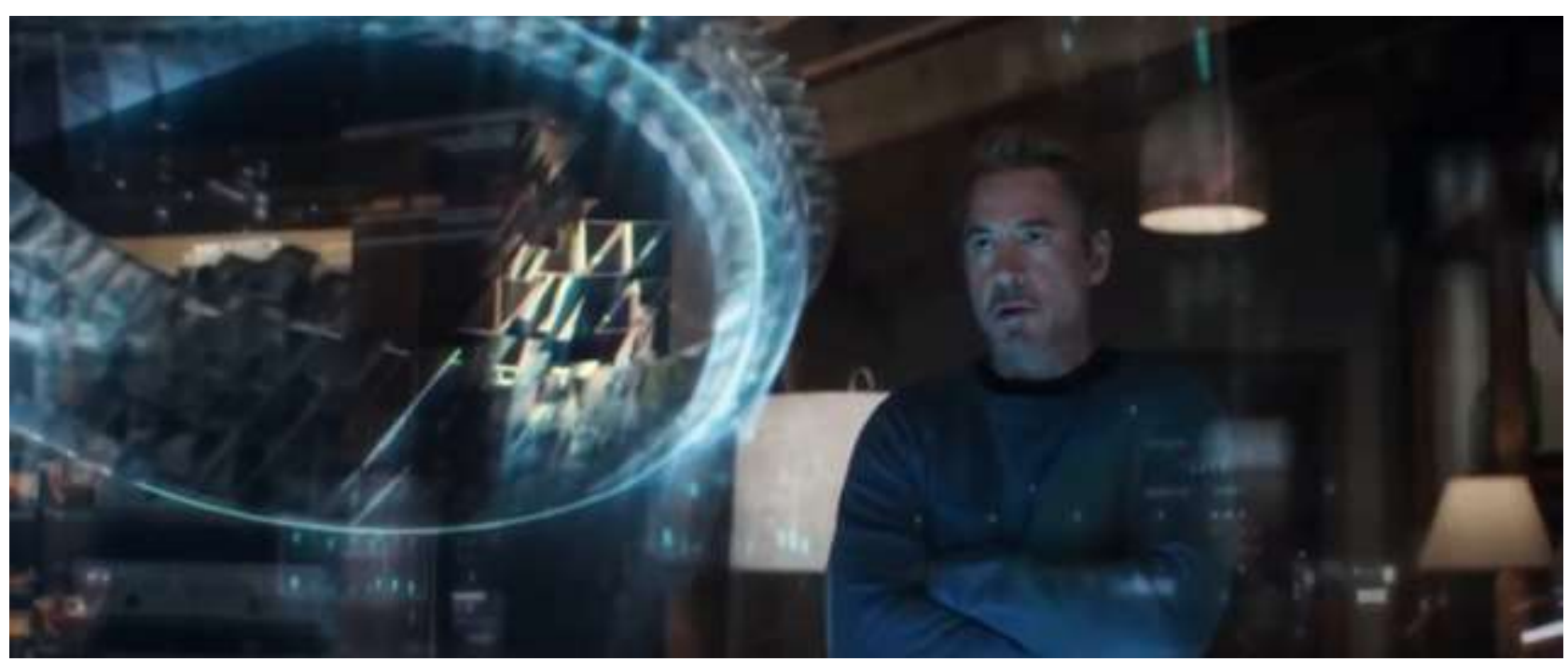

Figure 7. Creating Time Travel Machine

Source: Avengers: Endgame

Based on the scene of creating time travel, it can be concluded that Iron Man is a creative person. He used his knowledge and experience in order to create a time travel machine. The development of Avengers' technologies is supporteb by Tony's creativity. He also made an improvement for his armor after he experienced battle against Thanos. Because of Tony's creativity, Captain America, Rocket Racoon, War Machine, Nebula, Hawkeye, Black Widow, Ant Man, and Thor can use time travel machine and go to the past.

\section{\#Communicativeness}

The last type of character education values reflected from Avengers: Endgame movie was 'communicativeness'. This character education was reflected from how Avengers communicate each other while doing mission. Character education value communicativeness or to be communicative, was known as having the ability to do communication. The communicative person has ability to exchange and share ideas, feelings, words, or information with other people. Communicative value was reflected from the scene when the avengers communicate each others. 


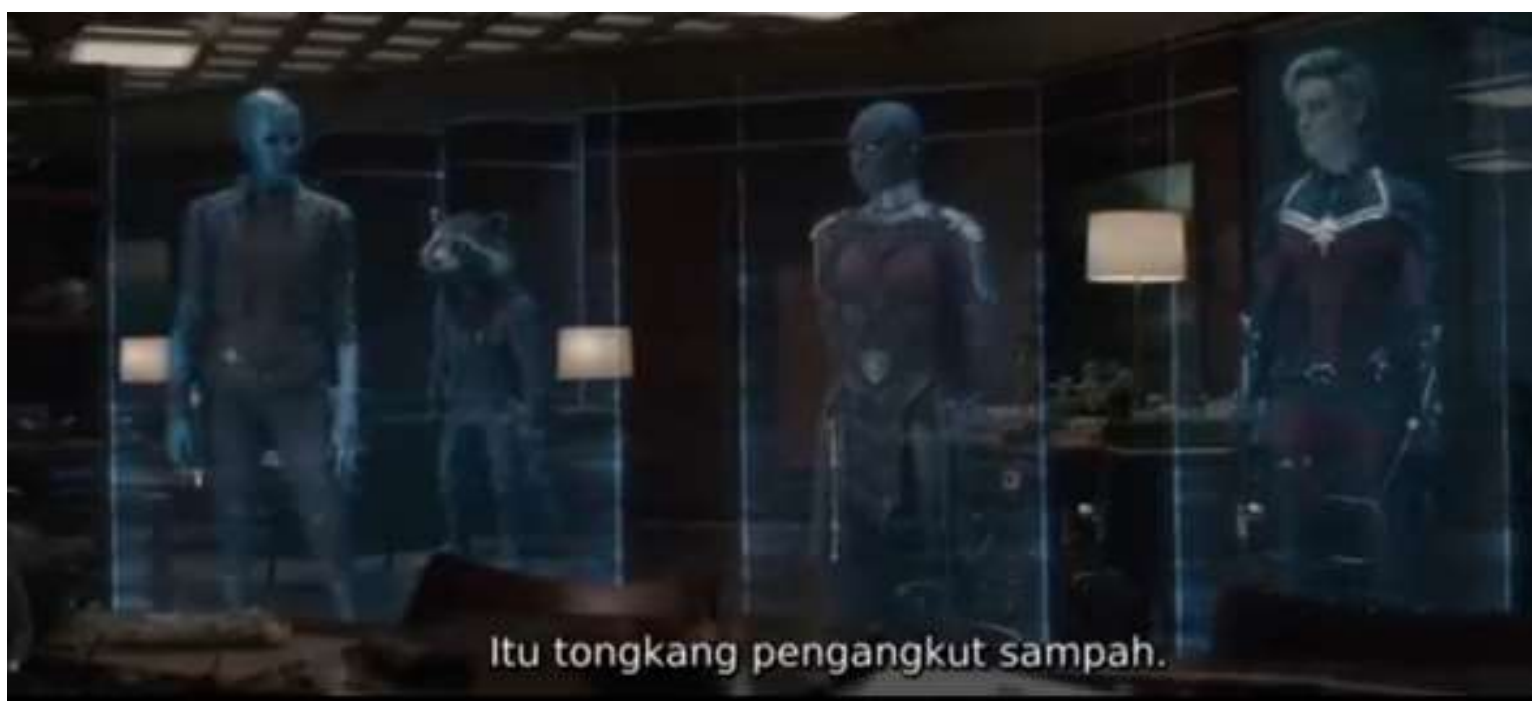

Figure 8. Avengers' Communication in Mission

Source: Avengers: Endgame

The Avengers always communicate each other while they do the missions. They communcate each other in order to discuss their strategies and planning. They also share the ideas about the world. Every Avenger character is communcative person who has ability to transfer and share ideas, feelings, words, or information. Because they are commincative people, Avengers become the powerful super heroes alliance.

\section{CONCLUSION}

In conclusion, based on the results of this study, watchim movie is one way to learn character education. Avengers: Endgame was a great movie that taught the viewers valuable lessons called character education. Those character education values were reflected by using the characteristic of character education values theories. After analyzing the scene and the script of Avengers: Endgame, there were eight types of character education values reflected from this movie. They were responsibility, honesty, hardworking, tolerance, curiosity, patriotism, creativity, and communicativeness.

\section{REFERENCES}

Ary, D. (2010). Introduction to Research in Education Eighth Edition . Canada : Wadsworth Cengage Learning .

Esianita, P., \& Widyawati, W. (2020). Character Education Values on "Aquaman" Movie. Eltall (English Language Teaching, Applied Linguistics and Literature) , 1-8.

Faiziyah, N., \& Fachrurrazy. (2013). The Implementation of Character Building in English Subject at Junior High School 3 Malang. Journal-Online UM, 4(2) , 1-21. 
IMDb. (2019). Avengers: Endgame. Retrivied 4 5, 2021, from IMDb: m.imdb.com/title/tt4154796/

Jannah, M. (2018). Educational Values in "Akeelah and the Bee" Movie. Banda Aceh : ArRaniry State Islamic University Darussalam Banda Aceh.

Kemendiknas. (2010). Buku Panduan Pendidikan Karakter SMP. Jakarta: Badan Penelitian dan Pengembangan Pusat Kurikulum.

Mahmud. (2016). Metodologi Penelitian . Mojokerto: Thoriq Al-Fiqri.

Mardewi, T., Wanto, E., \& Indriyani, F. (2020). Character Educational Value of Stephen Hawking in Theory of Everything Movie Directed by James Marsh. ENGLISH EDUCATION Journal of English Teaching and Research Vol. 5 , 49-51.

Mukarromah, S. (2019). An Analysis of Character Eduactional Values in "Zootopia" Movie Script. Ponorogo: State Institute of Islamic Studies Ponorogo.

Pala, A. (2011). The Need for Character Education. International Journal of Social Sciences and Humanity Studies , 23-31.

Wardani, E. A., Tasnim, Z., \& Eko B, W. (2019). Analysis of Character Education Values in the English Textbook for the Twelfth Grade Senior High School: Bahasa Inggris SMA/SMK. Jurnal Pendidikan Karakter , 231-244. 